\title{
Fruit Soil Survey
}

$\mathrm{T}$ HE county of Kent, along with its neighbours Surrey and Sussex, became classical ground for the scientific survey of soils after the publication of "A Report on the Agriculture and Soils of Kent, Surrey and Sussex" by Sir Daniel Hall and Sir John Russell. Now, more than thirty years after that auspicious pioneer work, a "Survey of the Fruitgrowing Areas on the Lower Greensand in Kent" has been published by the Ministry of Agriculture and Fisheries (Bulletin No. 80. Pp. 81. H.M. Stationery Office, 1934. 3s. net). The Survey reports extensive work by Messrs. W. A. Bane, of East Malling Research Station, and G. H. Gethin Jones, of the South Eastern Agricultural College, Wye, and collects the results of a large number of observations.

It is only by the application of intensive methods of soil survey to small areas that they can be made of use to the practical grower. This has been done in the survey under review, and as a result, twenty-six types of soil have been recognised. Of these, only about six are regarded as naturally good for the growth of fruit, though others are classified as average or fairly good. Good soils cover extensive areas. Estimation of the suitability of particular soils for the needs of a particular crop is not easy; but the survey under review takes into account such factors as soil water, drainage and the less tangible effects "of such features as management.

The solid geology of the district is illustrated by a coloured map inserted in the Bulletin, and by a very useful diagrammatic section, in addition to descriptions in the text. Methods of soil classification are based upon the American method of field examination. Soils which have the same geological origin, similar water relations and profile, and analogous topographical position are placed in the same series. Each series is subdivided into types according to the texture of the surface soil, and each type may have one or more 'phases', according to variation in such features as depth or drainage.

Several valuable conclusions emerge from the report. The area of Kent covered by the Lower Greensand is undoubtedly very suitable for the growth of tree and bush fruit. Water conditions of soils in this area seem to determine their suitability for fruit growing, rather than physical nature of the particles. The question of draining is dealt with in an interesting manner, and it is shown that two soil series known as the Malherbe and Cox Heath are both troubled by excess of water in winter. The Mal. herbe series can be improved, by draining, for a certain type of fruit growing, whilst it is "doubtful whether the cost of such work would be repaid on the Cox Heath series". Heavier soils derived from the Folkestone sand strata can be used for fruit growing, if careful manuring, particularly with potash, is performed. Lighter soils from the same strata cannot be improved profitably.

Soil survey has been correlated carefully with the use of such special practices as ringing, and studies of varying root systems in different soils and on different rootstocks open up interesting possibilities for future work. The survey of existing fruit plantations reveals the fact that a large proportion contain apple trees which are unsuited to modern needs, are grafted upon rootstocks unsuited to the type of crop desired, and are not spaced to the best advantage.

There can be no better advocate of improved cultivation than the presence of East Malling Research Station in the area under survey. Results from this Station are of the highest practical value, and indicate, among other things, that fruit of dessert quality might be grown more extensively in the area, rather than that of culinary grade as at present. The Survey is already welcomed by the more progressive trade organisations as a valuable contribution to the ageold industry of fruit-growing.

\section{Pygmies of Central Africa}

$\mathrm{T}$ HE difficulty of placing the pygmies of Central Africa in such a position in a scheme of ethnological classification as will be generally accepted as convineing is well known. To a certain extent this is due to the lack of adequate detailed information bearing on their physical characters ; but in part it also arises from the fact that such material as has been available did not readily admit of comparative study of variation among the pygmies themselves. This applied especially to the question of the degree to which they were related to, or showed evidence of admixture with, the peoples of greater stature, the negroes, among whom they had their habitat.

It was, therefore, welcome news to anthropologists that Paul Schebesta, who had made a study of the pygmies of the East, and more especially of the Semang of the Malay Peninsula, was undertaking an expedition to the Congo for the purpose of studying and measuring the African pygmies.

P. Schebesta's expedition was in the field in 192930. It was made possible by the generous assistance of the Charles University, Prague, the Comenius University, Bratislava, and a contribution was received from the Dr. Aleš and Mrs. Marie Hrdlička Fund. The material collected has been analysed by Prof. Victor Lebzelter, who had dealt similarly with the Semang material collected by P. Schebesta, and the combined report has been published by the Czech Academy of Sciences and Arts*, the tables of original measurements being included and an English translation appended.

In the first section of the report, P. Schebesta deals with the demography and morphology of the pygmies, the anthropological analysis by Prof. Lebzelter forming the second part. The peoples or groups who came under observation fall into two categories - the pure pygmies of the Ituri Forest region, who are distinguished by special somatic features, and the pygmiforms - a term here preferred by the authors to 'pygmoid', as this latter term is generally used to include peoples who approach the

* Ceská Akademie V̌̉ a Umenń (Académie Tchèque des Sciences et des Arts). Trida (Class) 2: Anthropologica. Anthropologie Stredo afrických Pygmejú v. Belgickém Kongu (Anthropology of the Central African Pygmies in the Belgian Congo). Napsali $P$. Sebesta a $Y$ Lebzelter. Pp. $143+66$ plates. (Prague : Ceska Akademie Věd a Lebzelter. Pp. 